\title{
Oral and Oropharyngeal Squamous Cell Carcinoma in Our Population: The Clinic-Pathological and Morphological Description of 153 Cases
}

\author{
Carcinoma de Células Escamosas Oral y Orofaríngeo en Nuestra Población: \\ Descripción Clínico-Patológica y Morfológica de 153 Casos
}

\author{
A. K. Agarwal; Ashwani Sethi; Deepika Sareen \& Shruti Dhingra
}

AGARWAL, A. K.; SETHI, A.; SAREEN, D. \& DHINGRA, S. Oral and oropharyngeal squamous cell carcinoma in our population: The clinic-pathological and morphological description of 153 cases. Int. J. Morphol., 29(3):686-693, 2011.

SUMMARY: Oral cavity and oropharynx are one of the commonest sites for cancers in our population due to a high prevalence of tobacco use, especially chewing, in our country. The objective of this study was to prospectively assess the clinico-pathological and morphological aspects of the patients presenting to us with these malignancies. We studied 153 patients with oral and oropharyngeal squamous cell carcinoma who were managed in the department of otolaryngology and head and neck surgery between January 2006 and December 2007 at Maulana Azad Medical College and associated hospitals in New Delhi. There were 127 male patients (83\%) and 26 females (17\%) with ages ranging from 22 years to 70 years. One hundred and eleven patients (73\%) presented with oral cavity and 42 patients $(27 \%)$ with oropharyngeal carcinomas. Most common site of presentation in the oral cavity was the buccal mucosa, whereas, base of tongue was the commonest site in the oropharynx. Amongst the oral cavity cancers, 51 each (46\% each) were well differentiated and moderately differentiated, whereas, $9(8 \%)$ were poorly differentiated cancers. However, amongst the oropharyngeal cancers, 27 $(64 \%)$ were moderately differentiated and $15(36 \%)$ were poorly differentiated. Overall, 73 patients presented with lymphadenopathy on presentation, out of which, 44 patients were those with oral cavity and 29 with oropharyngeal cancers. There was a significant correlation between the site (i.e. oral cavity or orophaynx) and lymphadenopathy on presentation. Fifty nine patients (39\%) presented to us with early stage disease (i.e. stage I and II), whereas, 94 patients (61\%) presented with late stage disease (i.e. stage III and IV). There was a significant correlation between the site (i.e. oral cavity or oropharynx) and stage at presentation.

KEY WORDS: Squamous cell carcinoma; Oral cavity; Oropharynx; Head and neck.

\section{INTRODUCTION}

Although, there have been reports of an overall increasing incidence of head and neck squamous cell carcinoma (HNSCC) in western population over the past few years, its incidence is reported to be declining in our country (Gaitán-Cepeda et al., 2010). Still, it remains one of the commonest sites for cancer in our country (Elango et al., 2006; Mehrotra et al., 2005). Amongst the HNSCCs, carcinoma of the oral cavity and oropharynx predominates in our population (Elango et al.; Yeole et al., 2006). The prognosis of patients with these cancers depends upon a wide range of factors that may be grouped into patient-, tumour- and treatment-related (Massano et al., 2006). The tumour related factors include the size of tumour, site of tumour, thickness of tumour, degree of differentiation and spread into regional lymph nodes (González-García et al., 2009; Weijers et al.,
2009; Patel et al., 2009; Rivera et al., 2008; Shaw et al., 2009). The present study is aimed at identifying the prevalence of tumour-related morphological and pathological factors such as the site, stage, degree of differentiation and lymph node involvement in oral and oropharyngeal squamous cell carcinomas in our population.

\section{PATIENT AND METHOD}

One hundred and fifty three patients with biopsy proven squamous cell carcinoma of the oral cavity and oropharynx who were treated in the Department of Otolaryngology and Head and Neck Surgery at Maulana 
Azad Medical College and associated Lok Nayak Hospital between January 2006 and December 2007 were included in the study. Patients with other malignancies (i.e. lymphoma, sarcoma, minor salivary gland malignancies) and patients unwilling to comply were excluded.

All the patients underwent a clinical staging in accordance with the TNM system of the American Joint Commission of Cancer Staging (2002) at the time of presentation. On the basis of staging, the patients were divided into 2 groups: Group 1 with early stage disease at presentation (i.e. stage I and II) and group 2 with late stage disease at presentation (i.e. stage III and IV).

Age, sex, predisposing factors, previous treatment history, duration of symptoms, clinical evaluation and histopathological (biopsy) records were recorded. Required laboratory and radiological investigations were done and the patients were managed according to the standard protocols.

\section{RESULTS}

Of the 153 patients, $127(83 \%)$ were male and 26 $(17 \%)$ were female. The youngest patient was 22 years and the eldest 70 years (Fig. 1). One hundred and eleven patients (73\%) presented with oral cavity and 42 patients (27\%) with oropharyngeal carcinomas.

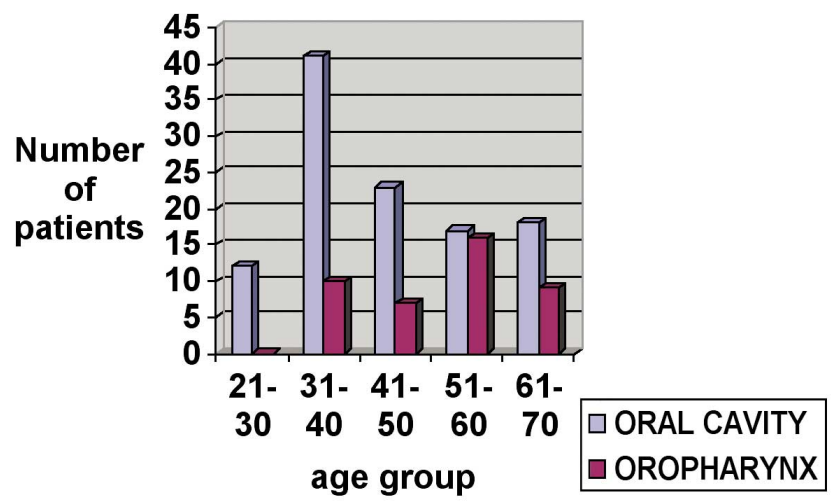

Fig. 1. Showing age distribution of patients with oral and oropharyngeal cancer.
Of the 111 patients presenting with oral cavity cancer, $90(81 \%)$ were male and $21(19 \%)$ were female. The commonest site was found to be buccal mucosa (41\%) (Table I). The most common presenting symptom was a mass/ulcer in the oral cavity, followed by pain, dysphagia and trismus. The most commonly identifiable risk factor was tobacco chewing (Table II). Fifty-one patients each had a well differentiated and a moderately differentiated carcinoma on histopathological evaluation, whereas, 9 patients had a poorly differentiated squamous cell carcinoma (Table III). On examination, the tumour mass was exophytic/proliferative in appearance in 99 patients and ulcerative/infilterative in 12 patients (Table IV) (Figs. 2 to 8). Forty-four patients had cervical lymphadenopathy on presentation.

Table I. Sites of presentation in the oral cavity.

\begin{tabular}{lc}
\hline Sub-site & Number of patients \\
\hline Upper lip & Nil \\
Lower lip & 09 \\
Buccal mucosa & 45 \\
Oral tongue & 18 \\
Floor of mouth & 09 \\
Lower alveolus & 12 \\
Upper alveolus/Hard palate & 18 \\
\hline Total & 111 \\
\hline
\end{tabular}

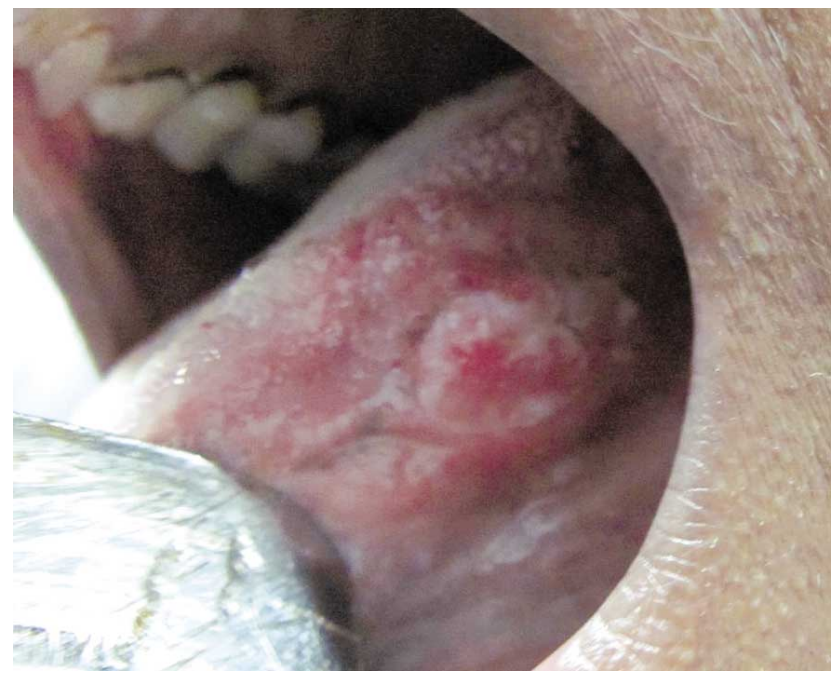

Fig. 2. Showing proliferative growth involving oral tongue.

Table II. Number of patients with various risk factors for different sub-sites in the oral cavity.

\begin{tabular}{llccccccc}
\hline Sub-site & & $\begin{array}{c}\text { Upper } \\
\text { lip }\end{array}$ & $\begin{array}{c}\text { Lower } \\
\text { lip }\end{array}$ & $\begin{array}{c}\text { Buccal } \\
\text { mucosa }\end{array}$ & $\begin{array}{c}\text { Oral } \\
\text { tongue }\end{array}$ & $\begin{array}{c}\text { Floor of } \\
\text { mouth }\end{array}$ & $\begin{array}{c}\text { Lower } \\
\text { alveolus }\end{array}$ & $\begin{array}{c}\text { Upper } \\
\text { alveolus }\end{array}$ \\
\hline Risk Factor $(\mathbf{n}$ & Smoking & Nil & Nil & 18 & 07 & 06 & 04 & 15 \\
of patients) & Tobacco chewing & Nil & 11 & 32 & 13 & 02 & 14 & 03 \\
& Alcohol & Nil & Nil & 04 & 04 & 05 & 05 & Nil \\
\hline
\end{tabular}




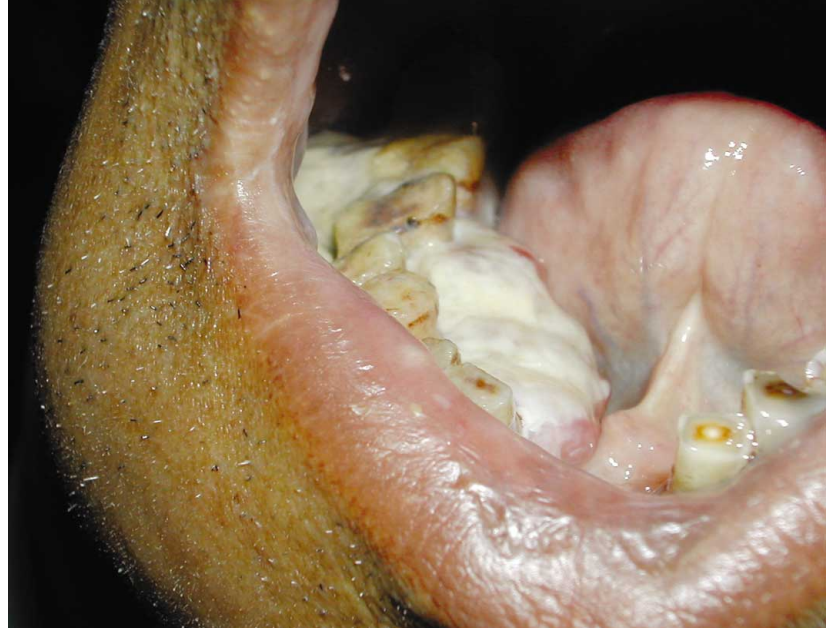

Fig. 3. Showing proliferative growth involving lower alveolus.

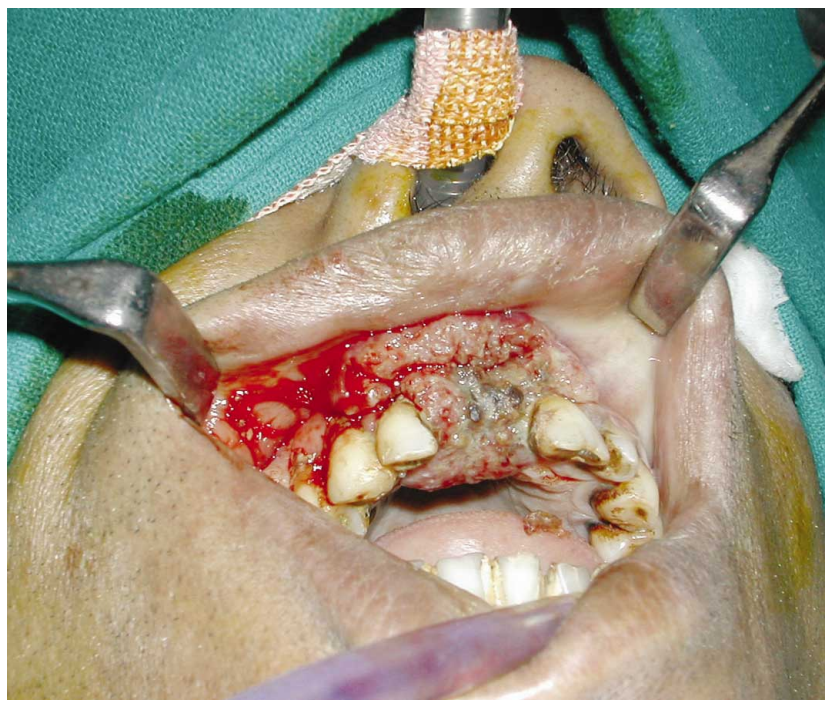

Fig. 4. Showing proliferative growth involving upper alveolus.

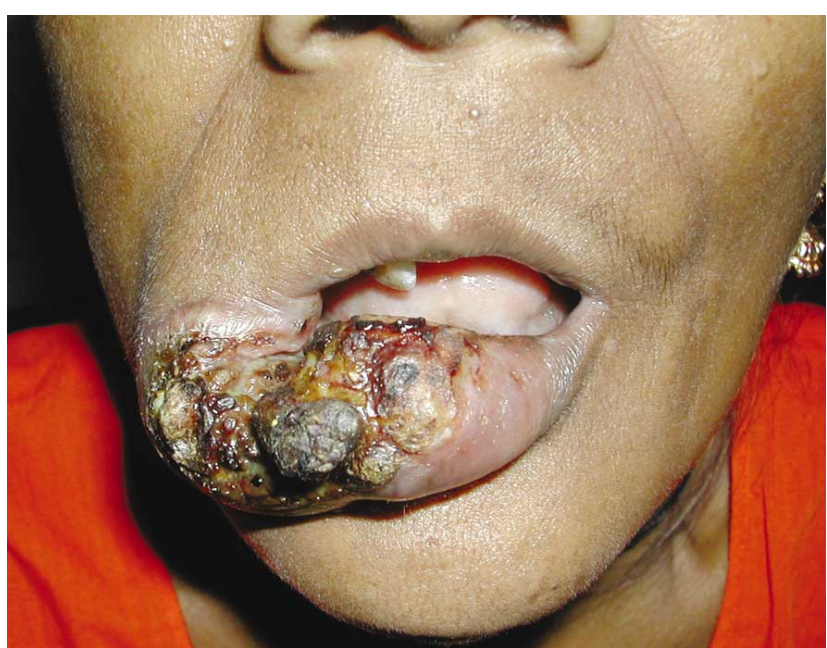

Fig. 5. Showing proliferative growth involving lower lip.

688

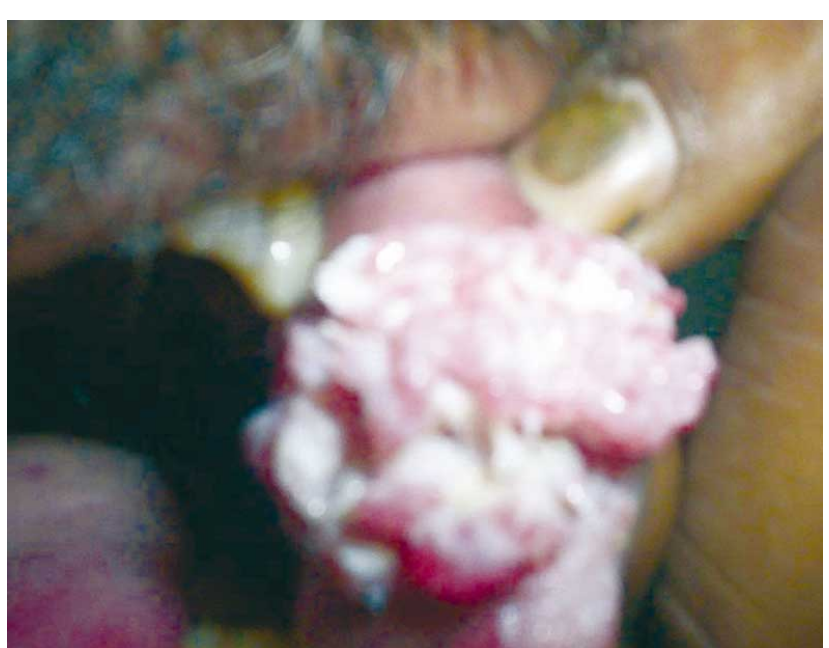

Fig. 6. Showing proliferative growth involving buccal mucosa.

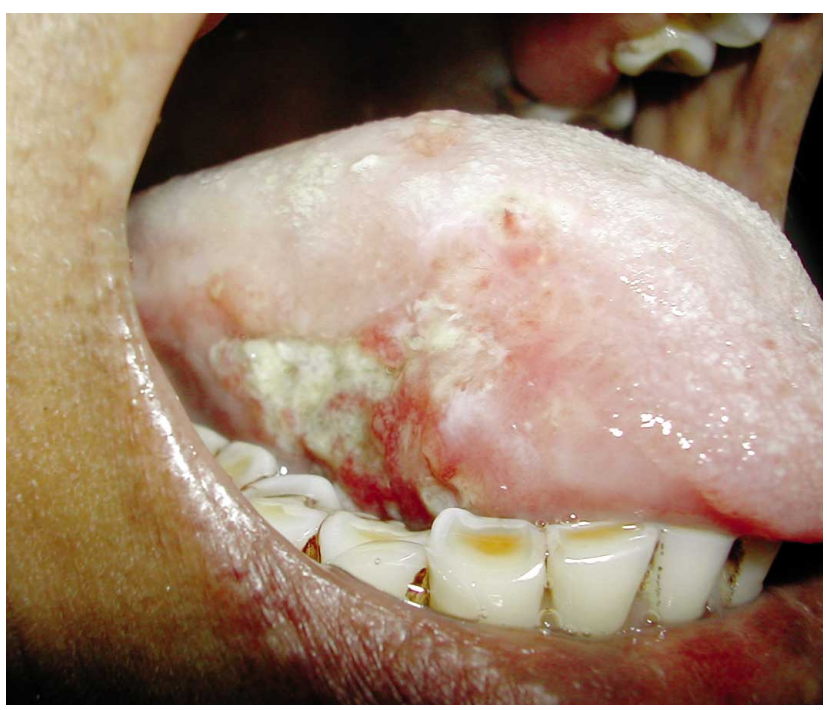

Fig. 7. Showing infiltrative growth involving oral tongue.

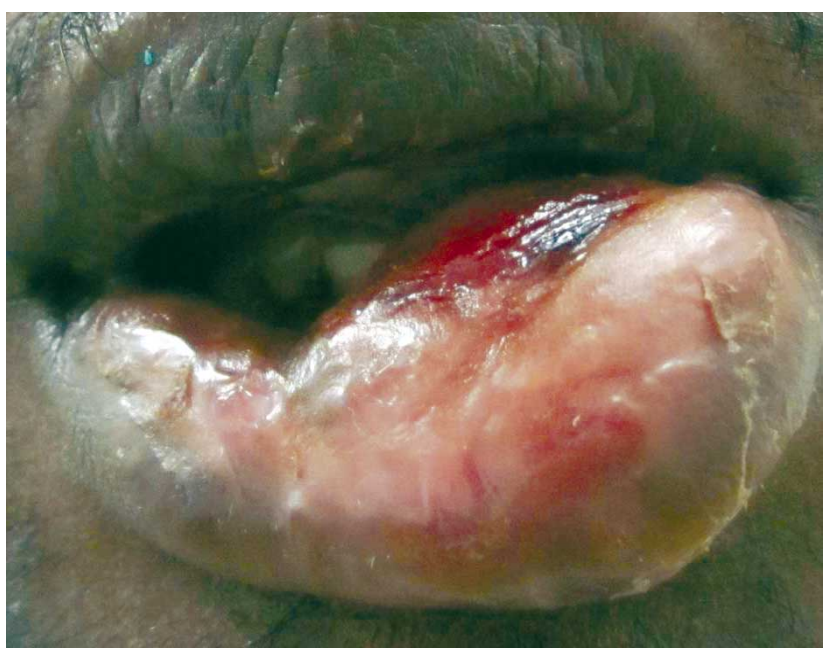

Fig. 8. Showing infiltrative growth involving lower lip. 
Of the 42 patients presenting with oropharyngeal cancer, $37(88 \%)$ were male and $5(12 \%)$ were female. The commonest site was found to be the base of tongue (Table $\mathrm{V})$. The commonest presenting symptom was dysphagia. The most common identifiable risk factor was smoking (Table VI). Twenty-seven patients had a moderately differentiated squamous cell carcinoma on histopathological evaluation, whereas, 15 patients had a poorly differentiated squamous cell carcinoma (Table VII). On examination, the tumour mass was exophytic/proliferative in appearance in 27 patients and ulcerative/infiltrative in 15 patients (Table VIII), (Figs. 9 and 10). Twenty-nine patients had cervical lymphadenopathy on presentation.

Of the 153 patients, 59 patients (39\%) presented with early stage disease (i.e. stage I and II) and 94 patients (61\%) presented with late stage disease (i.e. stage III and IV).

Of the 59 patients presenting with early stage disease, 50 were male and 9 were female with 51 patients presenting with oral cavity cancer and 8 patients with oropharyngeal cancer. Most of the patients with early stage disease presented in the age group of 31 to 40 years (Fig. 11).

Of the 94 patients presenting with late stage disease, 77 were male and 17 were female with 60 patients presenting with oral cavity cancer and 34 patients with oropharyngeal cancer. Most of the patients presented in the age group of 31 to 40 years (Fig. 2). On using Fisher Exact test, there was found to be a significant correlation $(\mathrm{p}<0.05)$ between the site (i.e. oral cavity or oropharynx) and stage at presentation and lymphadenopathy at presentation.

Table III. Showing histological differentiation of tumours at various sub-sites in the oral cavity.

\begin{tabular}{lccc}
\hline \multirow{2}{*}{ Sub-site } & \multicolumn{3}{c}{ Histological grade of differentiation (n of patients) } \\
\cline { 2 - 4 } & Well differentiated & Moderately differentiated & Poorly differentiated \\
\hline Upper lip & Nil & Nil & Nil \\
Lower lip & 05 & 04 & Nil \\
Buccal mucosa & 14 & 22 & 09 \\
Oral tongue & 10 & 08 & Nil \\
Floor of mouth & $\mathrm{Nil}$ & 09 & $\mathrm{Nil}$ \\
Lower alveolus & 08 & 04 & $\mathrm{Nil}$ \\
Upper alveolus/Hard palate & 14 & 04 & $\mathrm{Nil}$ \\
\hline Total & 51 & 51 & 09 \\
\hline
\end{tabular}

Table IV. Showing gross appearance of tumours of oral cavity.

\begin{tabular}{lccc}
\hline & \multicolumn{3}{c}{ Number of patients } \\
\cline { 2 - 4 } Site & Exophytic/Proliferative & Ulcerative/Infiltrative & Total \\
\hline Lower lip & 08 & 01 & 09 \\
Buccal mucosa & 40 & 05 & 45 \\
Oral tongue & 14 & 04 & 18 \\
Floor of mouth & 09 & 00 & 09 \\
Lower alveolus & 12 & 00 & 12 \\
Upper alveolus & 16 & 02 & 18 \\
\hline
\end{tabular}

Table V. Sites of presentation in the oropharynx.

\begin{tabular}{lccccc}
\hline Sub-site & Tonsil & Base of tongue & Soft palate & Posterior pharyngeal wall & Total \\
\hline n of patients & 15 & 21 & 06 & Nil & 42 \\
\hline
\end{tabular}

Table VI. Number of patients with various risk factors for different sub-sites in the oropharynx.

\begin{tabular}{llcccc}
\hline Sub-site & & Tonsil & Base of tongue & Soft palate & Posterior pharyngeal wall \\
\hline Risk & Smoking & 10 & 18 & 05 & Nil \\
Factor $\quad(n$ & Tobacco chewing & 05 & Nil & 03 & Nil \\
of patients) & Alcohol & 06 & 08 & 07 & Nil \\
\hline
\end{tabular}


Table VII. Showing histological differentiation of tumours at various sub-sites in the oropharynx.

\begin{tabular}{lccc}
\hline & \multicolumn{3}{c}{ Histological grade of differentiation (n of patients) } \\
\cline { 2 - 4 } Sub-site & Well differentiated & Moderately differentiated & Poorly differentiated \\
\hline Tonsil & Nil & 07 & 08 \\
Base of tongue & Nil & 17 & 04 \\
Soft palate & Nil & 03 & 03 \\
Posterior pharyngeal wall & Nil & Nil & Nil \\
\hline Total & Nil & 27 & 15 \\
\hline
\end{tabular}

Table VIII. Showing gross appearance of tumours of oropharynx.

\begin{tabular}{lccc}
\hline & \multicolumn{3}{c}{ Number of patients } \\
\cline { 2 - 4 } Site & Exophytic/Proliferative & Ulcerative/Infiltrative & Total \\
\hline Tonsil & 12 & 03 & 15 \\
Base of tongue & 09 & 12 & 21 \\
Soft palate & 06 & 00 & 06 \\
\hline
\end{tabular}

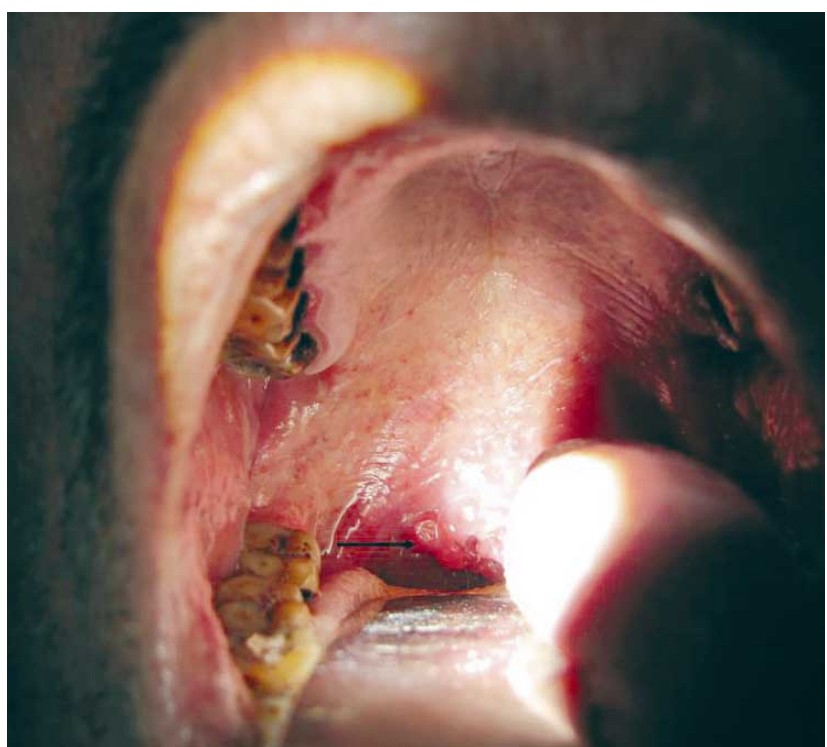

Fig. 9. Showing proliferative growth involving soft palate (black arrow).

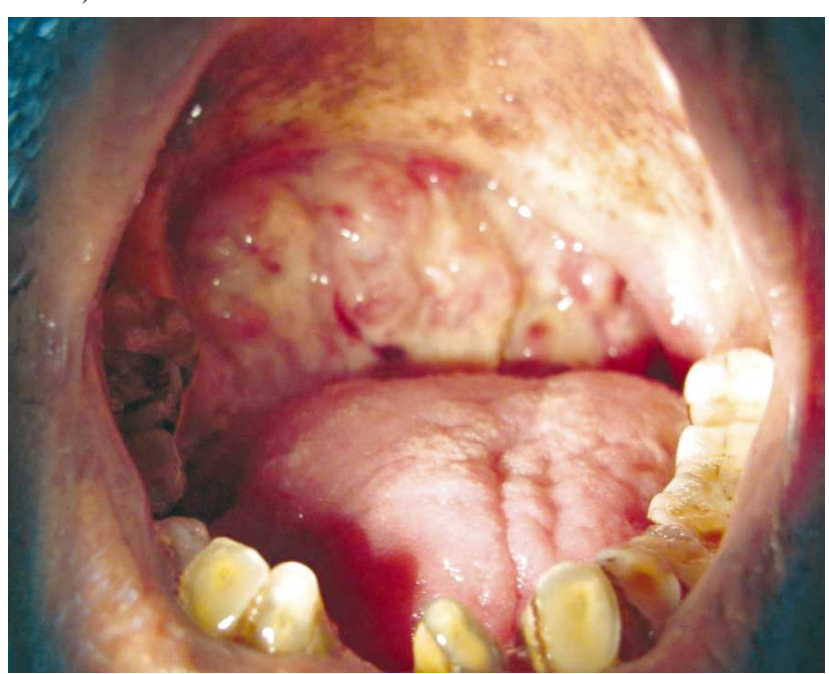

Fig. 10. Showing proliferative growth involving tonsil and adjoining soft palate.

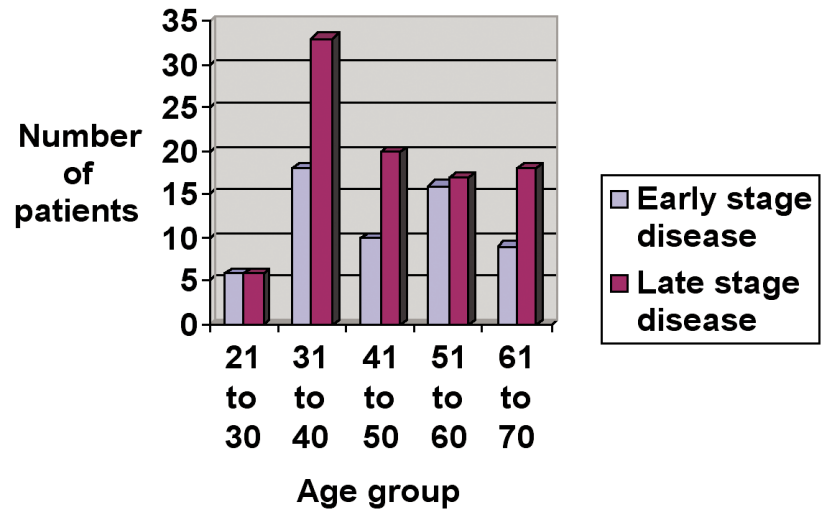

Fig. 11. Showing age distribution of patients presenting with early and late stage disease.

\section{DISCUSSION}

Head and neck is one of the commonest sites for squamous cell carcinomas in our country. Amongst HNSCCs, oral cavity and oropharyngeal carcinomas predominate (Elango et al.; Mehrotra et al.; Yeole et al., 2006). Squamous cell carcinoma of the oral cavity is the most frequently observed form of head and neck cancer in Southeast Asia and is the sixth most common cancer worldwide (Al-Swiahb et al., 2010).

India is a high-risk region for oral and oropharyngeal cancer due to a high prevalence of tobacco use, particularly chewing (in both sexes), bidi smoking and alcohol drinking in male population (Yeole et al., 2003). Our country accounts for a quarter of the world burden of oral cancer (Parkin et al., 1999). Apart from alcohol and tobacco, low level of 
education, gender, dietary habits and poor oro-dental hygiene have also been found to be associated with a high risk of oral and oropharyngeal cancer (Güneri et al., 2005).

Despite improvements in diagnosis and loco-regional treatment, the long-term survival in oral and oropharyngeal cancer has not increased significantly over the past four to five decades and is amongst the lowest of the major cancers world wide (Swango, 1996; Shiboski et al., 2000). The observed 5-year survival rate in an Indian population has been reported to be as low as $30.5 \%$ in a recent study (Yeole et al., 2003). Such low survival rates have been accredited to advanced age and advanced clinical stage at presentation. Other factors influencing the outcome of such cancers include tumour-related morphological and pathological factors like the degree of differentiation, site and size of tumour, etc. The present study is aimed at identifying such morphological and pathological characteristics of oral and oropharyngeal carcinomas in patients in our population.

Our study comprised 153 patients, out of which, $83 \%$ were male and $17 \%$ were female. This gender distribution was similar to a few of the studies in the past (Mehrotra et al.), whereas, some studies report a much higher incidence of females suffering from these cancers (Kumar et al., 2001; Güneri et al.). A few of the studies have reported an increasing incidence of these cancers in the females (Gaitán-Cepeda et al., 2010; Girod et al., 2009).

Of these, $73 \%$ of the patients had cancer of the oral cavity with buccal mucosa as the most common site (41\%). Although, oral tongue is considered the most common site for carcinoma in the oral cavity according to western literature (Watkinson et al., 2000; Rivera et al.), the rampant use of chewable tobacco can be attributed to the relatively higher incidence of involvement of buccal mucosa in our country (Mehrotra et al.; Kumar et al.). Seventeen percent of the patients in our study had oropharyngeal cancer with the base of tongue as the commonest site (50\%). The most commonly reported oropharyngeal site for cancer in western literature is the tonsil, whereas, some studies report base of tongue as the commonest site (Rivera et al.). Some of the studies have shown a significant association between the site of the tumour and overall prognosis, with the buccal mucosa tumours reportedly having a worse prognosis (Shaw et al.; Jerjes et al., 2010). The most commonly identifiable risk factors for both oral as well as oropharyngeal cancer in our study were tobacco chewing, smoking and alcohol intake. The other reported risk factors in the past include low socio-economic status, gender, dietary habits and poor oro-dental hygiene (Güneri et al.).
Thirty-nine percent of the patients presented to us with early stage disease (stage I and II). These results were comparable to a study on Indian population in the past where $32 \%$ of the patients presented with a localized cancer (Yeole et al., 2003). However, another Indian study in the past reported $50 \%$ of the patients presenting in early stages (Sankaranarayan, 1990). The clinical stage at the time of presentation has been shown to be significantly related to the overall prognosis, with the advanced stage disease having a worse prognosis (Watkinson et al.; GonzálezGarcía et al.).

Forty four out of 111 patients (40\%) with oral cavity cancers had cervical lymphadenopathy on presentation. Twenty nine out of 42 patients (69\%) with oropharyngeal cancers had cervical lymphadenopathy on presentation. The results were similar to most of the studies in the past (Rivera et al.; Batista et al., 2010). The presence or absence of metastatic lymphadenopathy has been reported to be the single most important prognostic factor for these cancers (Jerjes et al.; Rapoport et al., 2009).

Fifty one patients each out of 111 patients (46\% each) with oral cavity cancers had well and moderately differentiated squamous cell carcinoma, whereas, 9 patients $(8 \%)$ had a poorly differentiated squamous cell carcinoma. Twenty seven patients out of 42 (64\%) with oropharyngeal cancer had a moderately differentiated squamous cell carcinoma, whereas, 15 patients (36\%) had a poorly differentiated squamous cell carcinoma. None of the patients had a well differentiated squamous cell carcinoma. These results were similar to a few of the studies in the past (Rivera et al.; Jerjes et al.; AndishehTadbir et al., 2008). The degree of differentiation is considered as one of the important prognostic factor in head and neck cancers with poorly differentiated cancers having the worst prognosis (Weijers et al.; Al-Swiahb et al., 2010). Some studies have also reported a significant correlation between the degree of differentiation of the cancer and metastasis to regional lymph nodes, with less differentiated cancers having a greater propensity for metastasis (Rivera et al.).

Thus, the present study was aimed at analyzing the tumour-related morphological and pathological factors in patients suffering from oral and oropharyngeal squamous cell carcinomas in our population. The identification of these preoperative morphological and pathological features that prelude a higher risk for the appearance of local recurrences and, thus, affect the overall prognosis may be of potential interest in determining the overall prognosis of these cancers in our population and which patients should benefit of a closer regular follow-up. 
AGARWAL, A. K.; SETHI, A.; SAREEN, D. \& DHINGRA, S. El carcinoma de células escamosas oral y orofaríngeo en nuestra población: Descripción clínico-patológica y morfológica de 153 casos. Int. J. Morphol., 29(3):686-693, 2011.

RESUMEN: En nuestro país, la cavidad oral y orofaringe son los sitios más comunmente afectados por cáncer, debido a la alta prevalencia del consumo de tabaco, especialmente, el tabaco de mascar. El objetivo de este estudio fue evaluar prospectivamente los aspectos clínico-patológicos y morfológicos de los pacientes que acuden con estas malignidades. Se estudiaron 153 pacientes con carcinoma de células escamosas de la cavidad oral y orofaringe que fueron tratados en el Servicio de Otorrinolaringología y Cirugía de Cabeza y Cuello entre enero del 2006 y diciembre del 2007 en Maulana Azad Medical College y hospitales asociados en Nueva Delhi. Se evaluaron pacientes de ambos sexos, 127 hombres (83\%) y 26 mujeres (17\%) con edades entre 22 a 70 años. Ciento once pacientes (73\%) presentaron carcinoma de la cavidad oral y 42 (27\%) carcinomas de la orofaringe. El sitio más común de presentación en la cavidad oral fue la mucosa bucal, mientras que la base de la lengua fue el sitio más común de la orofaringe. Entre los cánceres de la cavidad oral, 51 (46\% cada uno) estaban bien diferenciados y moderadamente diferenciados, mientras que 9 ( $8 \%$ ) fueron escazamente diferenciado. Sin embargo, entre los cánceres de la orofaringe, 27 (64\%) fueron moderadamente diferenciados y $15(36 \%)$ fueron pobremente diferenciados. En total, 73 pacientes se presentaron con adenopatías, de los cuales, 44 pacientes fueron en la cavidad oral y 29 en la orofaringe. Se observó una correlación significativa entre el sitio (es decir, la cavidad oral u orofaringe) y la presentación de adenopatías. Cincuenta y nueve pacientes (39\%) se presentaron con enfermedad en estadio temprano (estadios I y II), mientras que 94 pacientes (61\%) se presentaron con enfermedad en estadio tardío (etapas III y IV). Se observó una correlación significativa entre el sitio (cavidad oral u orofaringe) y la etapa en la presentación.

PALABRAS CLAVE: Carcinoma de células escamosas; Cavidad oral; Orofaringe; Cabeza y cuello.

\section{REFERENCES}

Al-Swiahb, J. N.; Chen, C. H.; Chuang, H. C.; Fang, F. M.; Tasi, H. T. \& Chien, C. Y. Clinical, pathological and molecular determinants in squamous cell carcinoma of the oral cavity. Future Oncol., 6(5):837-50, 2010.

American Joint Committee on Cancer. Manual for staging of cancer. Philadelphia, JB Lippincott, 2002.

Andisheh-Tadbir, A.; Mehrabani, D. \& Heydari, S. T. Epidemiology of squamous cell carcinoma of the oral cavity in Iran. J. Craniofac. Surg., 19(6):1699-702, 2008.

Batista, A. C.; Costa, N. L.; Oton-Leite, A. F.; Mendonça, E. F.; Alencar R de, C. \& Silva, T.A. Distinctive clinical and microscopic features of squamous cell carcinoma of oral cavity and lip. Oral Surg. Oral Med. Oral Pathol. Oral Radiol. Endod., 109(3):e74-9, 2010.

Elango, J. K.; Gangadharan, P.; Sumithra, S. \& Kuriakose, M. A. Trends of head and neck cancers in urban and rural India. Asian Pac. J. Cancer Prev., 7(1):108-12, 2006.

Gaitán-Cepeda, L. A.; Peniche-Becerra, A. G. \& QuezadaRivera, D. Trends in frequency and prevalence of oral cancer and oral squamous cell carcinoma in Mexicans. A 20 years retrospective study. Med. Oral Patol. Oral Cir. Bucal, 16(1):e1-5, 2011.
Girod, A.; Mosseri, V.; Jouffroy, T.; Point, D. \& Rodriguez, J. Women and squamous cell carcinomas of the oral cavity and oropharynx: is there something new? J. Oral Maxillofac. Surg., 67(9):1914-20, 2009.

González-García, R.; Naval-Gías, L.; Román-Romero, L.; Sastre-Pérez, J. \& Rodríguez-Campo, F. J. Local recurrences and second primary tumors from squamous cell carcinoma of the oral cavity: a retrospective analytic study of 500 patients. Head Neck, 31(9):1168-80, 2009.

Güneri, P.; Cankaya, H.; Yavuzer, A.; Güneri, E. A.; Eris sen, L.; Ozkul, D.; El, S. N.; Karakaya, S.; Arican, A. \& Boyaciog $\mathrm{lu}, \mathrm{H}$. Primary oral cancer in a Turkish population sample: association with sociodemographic features, smoking, alcohol, diet and dentition. Oral Oncol., 41(10):1005-12, 2005.

Jerjes, W.; Upile, T.; Petrie, A.; Riskalla, A.; Hamdoon, Z.; Vourvachis, M.; Karavidas, K.; Jay, A.; Sandison, A.; Thomas, G. J.; Kalavrezos, N. \& Hopper, C. Clinicopathological parameters, recurrence, locoregional and distant metastasis in 115 T1-T2 oral squamous cell carcinoma patients. Head Neck Oncol., 2:9, 2010.

Kumar, S.; Heller, R. F.; Pandey, U.; Tewari, V.; Bala, N. \& Oanh, K. T. Delay in presentation of oral cancer: a multifactor analytical study. Natl. Med. J. India, 14(1):13-7, 2001. 
Massano, J.; Regateiro, F. S.; Januário, G. \& Ferreira, A. Oral squamous cell carcinoma: review of prognostic and predictive factors. Oral Surg. Oral Med. Oral Pathol. Oral Radiol. Endod., 102(1):67-76, 2006.

Mehrotra, R.; Singh, M.; Gupta, R. K.; Singh, M. \& Kapoor, A. K. Trends of prevalence and pathological spectrum of head and neck cancers in North India. Indian $J$. Cancer, 42(2):89-93, 2005.

Parkin, D. M.; Pisani, P. \& Ferlay, J. Global cancer statistics. C. A. Cancer J. Clin., 49(1):33-64, 1999.

Patel, R. S.; Clark, J. R.; Dirven, R.; Wyten, R.; Gao, K. \& O'Brien, C. J. Prognostic factors in the surgical treatment of patients with oral carcinoma. ANZ J. Surg., 79(1-2):1922, 2009.

Rapoport, A.; Ortellado, D. K. \& Dedivitis, R. A. Rationale for selective neck dissection in N+ oral cancer. Int. Surg., 94(4):339-43, 2009.

Rivera, H.; Nikitakis, N. G.; Correnti, M.; Maissi, S. \& Ponce, J. G. Oral and oropharyngeal cancer in a Venezuelan population. Acta Odontol. Latinoam., 21(2):175-80, 2008.

Sankaranarayan, R. Oral cancer in India: An epidemiologic and clinical review. Oral Surg. Oral Med. Oral Pathol., 69(3):325-30, 1990.

Shaw, R. J.; McGlashan, G.; Woolgar, J. A.; Lowe, D.; Brown, J. S.; Vaughan, E. D. \& Rogers, S. N. Prognostic importance of site in squamous cell carcinoma of the buccal mucosa. Br. J. Oral Maxillofac. Surg., 47(5):3569, 2009.

Shiboski, C. H.; Shiboski, S. C. \& Silverman, S. Jr. Trends in oral cancer rates in the United States, 1973-1996. Community Dent. Oral Epidemiol., 28(4):249-56, 2000.

Swango, P. A. Cancers of the oral cavity and pharynx in the United States: an epidemiologic overview. J. Public Health Dent., 56(6):309-18, 1996.

Watkinson, J. C.; Gaze, M. N. \& Wilson, J. A. Tumours of the lip and oral cavity. In: Stell and Maran's head and neck surgery. $4^{\text {th }}$ edn. Oxford, Butterworth-Heinemann, 2000. pp.275-318.

Weijers, M.; Snow, G. B.; Bezemer, P. D. \& van der Waal, I. Malignancy grading is no better than conventional histopathological grading in small squamous cell carci- noma of tongue and floor of mouth: retrospective study in 128 patients. J. Oral Pathol. Med., 38(4):343-7, 2009.

Yeole, B. B.; Ramanakumar, A. V. \& Sankaranarayanan, R. Survival from oral cancer in Mumbai (Bombay), India. Cancer Causes Control, 14(10):945-52, 2003.

Yeole, B. B.; Kurkure, A. P. \& Koyande, S. S. Geographic variation in cancer incidence and its patterns in urban Maharashtra, 2001. Asian Pac. J. Cancer Prev., 7(3):38590, 2006.

\author{
Correspondence to: \\ Dr. Ashwani Sethi \\ Department of ENT \& Head and Neck Surgery \\ Maulana Azad Medical College and associated L. N. Hospital \\ E-80, Naraina Vihar \\ New Delhi-110028 \\ INDIA
}

Phone No: 91-11-55342404

Email: dr_sethi@rediffmail.com

Received: 13-09-2010

Accepted: 02-05-2011 